\author{
Szczepan T. Praśkiewicz OCD ${ }^{1}$ \\ 0000-0003-4103-0735
}

Papieski Wydział Teologiczny „Teresianum” w Rzymie

\title{
Kunegunda Siwiec ze Stryszawy: osoba i przesłanie
}

Od 21 grudnia 2007 roku trwa proces beatyfikacyjny Kunegundy Siwiec ze Stryszawy, członkini Świeckiego Zakonu Karmelitów Bosych. Proces ten, zakończony na etapie diecezjalnym 28 października 2011 roku, znajduje się dziś w swej fazie rzymskiej. Kongregacja Spraw Kanonizacyjnych 1 marca 2013 roku wydała Decretum super validitate Inquisitionis Dioecesanae i trwają zaawansowane prace nad zredagowaniem stosownej Positionis super virtutibus et fama sanctitatis Servae Dei.

Równocześnie z pracami procesowymi sławę świętości kandydatki na ołtarze propagowało najpierw Towarzystwo Przyjaciół Kunegundy Siwiec, a obecnie czyni to Diakonia Świeckiego Zakonu Karmelitańskiego, która nosi jej imię. Towarzystwo, założone w 1998 roku, oddało

1 Szczepan Tadeusz Praśkiewicz OCD - dr hab. nauk teologicznych, absolwent Papieskich Wydziałów Teologicznych „Teresianum” i „Marianum” w Rzymie, były wykładowca „Teresianum”; redaktor serii wydawniczej Świętość Kanonizowana (14 tomów) oraz autor wielu publikacji z duchowości i hagiografii (Duchowość maryjna, Kraków 2008; Wybrane zagadnienia z prawa kanonizacyjnego i teologii świętości, Kraków 2013; Niebo Karmelu, Przemyśl 2018); w latach 1999-2005 prowincjał Krakowskiej Prowincji Karmelitów Bosych, obecnie jej postulator; konsultor Kongregacji Spraw Kanonizacyjnych. Adres do korespondencji: ul. Karmelicka 22, 34-100 Wadowice. E-mail: szczpn@gmail.com. 
niezastąpione przysługi i doprowadziło do otwarcia procesu beatyfikacyjnego Kunegundy. W 2012 roku zostało ono rozwiązane, a jego statutowe obowiązki przejęła Diakonia Kunegundy Siwiec przy Świeckim Zakonie Karmelitów Bosych ${ }^{2}$. Ze zrealizowanych przez Towarzystwo i Diakonię inicjatyw wymieńmy chociażby następujące: organizowanie dorocznych ogólnopolskich pielgrzymek do Stryszawy-Siwcówki z modłami o beatyfikację służebnicy Bożej (zawsze w komunii z hierarchią kościelną i wielokrotnie pod przewodnictwem biskupów lub wyższych przełożonych zakonnych); organizowanie sesji, wystaw, konkursów, recitali i przedstawień teatralnych o Kunegundzie; wydawanie plakatów, folderów, kart pocztowych, obrazków, CD, DVD, i inne $e^{3}$ Diakonia prowadzi stronę internetową ${ }^{4}$. Współpracowała także w realizacji filmu dokumentalnego o Kunegundzie pt. Mistyczka z gór w reżyserii Bogusławy Stanowskiej-Cichoń ${ }^{5}$.

Kunegunda Siwiec, prosta wiejska kobieta z Podbeskidzia wzbudza nadto zainteresowanie w kręgach naukowych, co dokumentują liczne rozprawy ${ }^{6}$ i publikacje ${ }^{7}$. Wyróżniają się spośród nich referaty wygłoszone

2 Zob. http://www.kundusia.pl/content/o-nas (3.01.2019).

3 Zob. dla przykładu: CD: Ścieżka na szczyt Kunegundy Siwiec; CD: Fragmenty rozmów Kundusi z Jezusem - czyta Izabela Drobotowicz-Orkisz; DVD: A nadzieja zawieść nie może. VII Pielgrzymka przyjaciół do grobu Kunegundy Siwiec (Siwcówka 2004); DVD: Z Karmelu na ołtarze. Audycja programów katolickich TVP Kraków z dn. 8 lutego 2008; I Konkurs Plastyczny pt. „Portret Kundusi”, Kraków 2011.

4 Zob. kundusia.pl

5 Zob. https://www.youtube.com/watch?v=_gg5OHF1-t4 (4.01.2019).

6 H. Wisiecka-Jęczalik, Terezjańska droga Kunegundy Siwiec 1876-1955, praca magisterska na Papieskim Fakultecie Teologicznym we Wrocławiu, Wrocław 2001; P. M. Strojecki, Życie duchowe Kunegundy Siwiec na podstawie „Miejsca Mojego Miłosierdzia i Odpoczynku”, praca magistersko-licencjacka na Wydziale Teologicznym Uniwersytetu Kardynała Stefana Wyszyńskiego w Warszawie, Radzymin 2004; S. Górnik, Doświadczenie mistyczne Rozalii Celaki Kunegundy Siwiec. Przesłanie dotyczace przyszłości Polski iświata, praca doktorska z Teologii Duchowości na Katolickim Uniwersytecie Lubelskim, Lublin 2006; A. Łączkowska, Eklezjalny wymiar posłannictwa Kunegundy Siwiec, praca magisterska na Wydziale Teologicznym Uniwersytetu Adama Mickiewicza w Poznaniu, Poznań 2008.

7 J. I. Adamska, Dlaczego właśnie Kundusia z Siwcówki? Rzecz o duchowości Kunegundy Siwiec, Tczew-Pelplin 1998; J. W. Gogola, Doświadczenie mistyczne Kundusi Siwiec, w: Mistyka i mistycy Karmelu, Kraków 2007, s. 379-391; B. Kucharski, Miejsce Bożego Miłosierdzia i Odpoczynku - Kunegunda Siwiec (1876-1955), w: Kobiety Bożego Miłosierdzia, Kraków 2007, s. 125-137; F. H. Stańczyk, Kunegunda Siwiec, Kraków 1999; P. M. Strojecki, Rozwój życia duchowego Kunegundy Siwiec 
podczas sesji naukowej zorganizowanej w 2006 roku w Karmelitańskim Instytucie Duchowości w Krakowie ${ }^{8}$. Poza tym nie brakuje publikacji w językach obcych? .

Chciejmy więc spoglądnąć syntetycznie na życie i przesłanie tej świeckiej karmelitanki, kandydatki na ołtarze.

\section{Szkic biogramu}

Autor biografii służebnicy Bożej Kunegundy Siwiec, Jerzy Zieliński OCD, nadał swej książce wymowny tytuł: Piękno ukryte $w$ prostocie ${ }^{10}$. Rzeczywiście z prostego życia bohaterki przebija prawdziwe piękno. Kundusia (tak ją nazywano w rodzinnej wiosce), córka Jana Siwca i Wiktorii Trzop, przyszła na świat 28 maja 1876 roku w Stryszawie. Rodzice byli dobrze sytuowaną, katolicką rodziną rolniczą. Od ich nazwiska

(1876-1955), w: Nova et vetera polskiej duchowości, red. M. Chmielewski, Lublin 2004, s. 208-227; S. Urbański, Kunegunda Siwiec (1876-1955), mistyka Trójcy Świętej, w: Mistyczki Niepodległej Polski 1918-2018: przesłanie Jezusa, Warszawa 2018, s. 136-144.

8 H. Stańczyk, Sylwetka Kundusi, kalendarium życia, w: Sesja kommemoracyjna o Kunegundzie Siwiec, Kraków 2006, s. 14-21 (Żyć Karmelem w Świecie, nr specjany); J. W. Gogola, Doświadczenia mistyczne Kundusi Siwiec, w: Sesja kommemoracyjna o Kunegundzie Siwiec, dz. cyt., s. 22-30; Sz. T. Praśkiewicz, Najświętsza Maryja Panna, Królowa Karmelu, na duchowej drodze Kunegundy Siwiec, w: Sesja kommemoracyjna o Kunegundzie Siwiec, dz. cyt., s. 31-41; A. Ruszała, Chrystus $w$ doświadczeniu duchowym Kunegundy Siwiec, w: Sesja kommemoracyjna o Kunegundzie Siwiec, dz. cyt., s. 42-49; M. Zawada, Teologia modlitwy według „,Miejsca Mojego Miłosierdzia i Odpoczynku", w: Sesja kommemoracyjna o Kunegundzie Siwiec, dz. cyt., s. 50-65; P. M. Strojecki, „Umiłuj mój Krzyż” - Cierpienie według „Miejsca Mojego Miłosierdzia i Odpoczynku”, w: Sesja kommemoracyjna o Kunegundzie Siwiec, dz. cyt., s. 66-73; P. Nyk, Nadprzyrodzone oświecenia Kunegundy Siwiec w świetle Biblii, w: Sesja kommemoracyjna o Kunegundzie Siwiec, dz. cyt., s. 74-82; J. I. Adamska, Sztafeta miłosierdzia, w: Sesja kommemoracyjna o Kunegundzie Siwiec, dz. cyt., s. 83-94.

9 T. Kalniuk, A folk mystic - Cunegonde Siwiec from Stryszawa: http://kundusia.pl/sites/ default/files/A_folk_mystic-Cunegonde_Siwiec_from_Stryszawa.pdf (4.01.2019); A. Marsili, Siwiec Cunegonda, serva di Dio, w: Bibliotheca Sanctorum, Terza appendice, Roma 2013, s. 10871089; Sz. T. Praśkiewicz, Cunegonda Siwiec OCDS en camino hacia los altares, Kraków 2012), s. 165-176 (Itineria Spiritualia, 5). Zob. także: http://kundusia.pl/content/information-english (4.01.2019).

10 J. Zieliński, Piękno ukryte w prostocie. Życie Służebnicy Bożej Kunegundy Siwiec OCDS, Kraków 2010. 
wziął nazwę cały przysiółek, zwany do dziś Siwcówką. Siwcowie zajmowali się uprawą roli i pasterstwem. Uchodzili za ludzi pracowitych i pobożnych i tak wychowywali swoje dzieci. Już w dniu narodzin Kunegunda została ochrzczona w kościele pw. Nawiedzenia Najświętszej Maryi Panny w Suchej Beskidzkiej. Do Pierwszej Komunii św. przystąpiła ona w dziesiątym roku życia, natomiast sakrament bierzmowania przyjęła 3 września 1897 roku.

Od lat dziecięcych Kundusia pracowała w polu, pomagała matce przy pracach domowych, pasała krowy i owce. Stryszawa nie posiadała szkoły. Pisania i czytania oraz podstaw arytmetyki stryszawskie dzieci uczyły się u światlejszych gospodarzy w okresie zimy, gdy nie było prac polowych. Kunegunda nauczyła się czytać i jedynie podpisywać.

Z natury swej pobożna, Kundusia starała się zawsze pogłębiać swoje życie religijne. Zauważa się to szczególnie po ukończeniu przez nią dwudziestego roku życia, co zbiegło się z rekolekcjami głoszonymi w parafii przez redemptorystę, o. Bernarda Łubieńskiego (1846-1933), kandydata na ołtarze. Za jego radą zrezygnowała z zamążpójścia, by jako osoba samotna służyć Bogu i bliźnim ${ }^{11}$. Już 2 lutego 1897 roku wstąpiła do Apostolstwa Modlitwy przy parafii św. Anny w Stryszawie ${ }^{12}$, a około 1902 roku ukończyła w Sidzinie kurs katechezy dla ludowych katechetek, zwanych sidziniarkami ${ }^{13}$. Od tej pory pomagała dzieciom, młodzieży i dorosłym przygotować się do sakramentów świętych i przybliżyć się do Boga. Sprzedawszy część ze swojej ziemi, pomagała w studiach klerykowi Józefowi Czerneckiemu ${ }^{14}$. W 1923 roku zapisała się w wadowickim

11 Zob. H. F. Stańczyk, Kundusia z Siwcówki (Kunegunda Siwiec), Kraków 1996, s. 27-28.

12 Zob. H. F. Stańczyk, Kundusia z Siwcówki (Kunegunda Siwiec), dz. cyt., s. 28-29.

13 Założycielem sidziniarek był ks. Wojciech Blaszyński (1806-1866) z Chochołowa na Podhalu, który w 1844 roku objął parafię w Sidzinie. By zwalczać tam pijaństwo i brak oświaty zaangażował światlejsze parafianki, organizując dla nich kursy katechetyczne. Nazywane potocznie „sidziniarkami”, ślubowały one dziewictwo i uczyły górali katechizmu. Kunegunda pobierała nauki od jednej z uczennic ks. Blaszyńskiego, gdyż on sam już nie żył. Zginął bowiem tragicznie podczas doglądania budowy kościoła w Chochołowie (B. Przybyszewski, Blaszyński Wojciech, w: Encyklopedia katolicka, t. 2, red. F. Gryglewicz, Lublin 1976, s. 657).

14 Józef Czernecki (1894-1949), syn stryszawskigo organisty Michała Czrneckiego był pierwszym kapłanem pochodzącym ze Stryszawy. Wspomagany materialnie przez Kunegundę ukończył w 1922 roku lwowskie seminarium duchowne i przyjął święcenia kapłańskie, 
klasztorze karmelitańskim do Bractwa Dzieciątka Jezus ${ }^{15}$, a następnie wstąiłła tamże do Trzeciego (obecnie Świeckiego) Zakonu Karmelitów Bosych, przyjmując imię Teresa od Dzieciątka Jezus ${ }^{16}$.

Wraz z młodszym bratem Michałem, współpracując z ks. Józefem Czerneckim, Kunegunda oddała część rodzinnego terenu pod budowę Zakładu Naukowo-Wychowawczego dla Dziewcząt, prowadzonego w Siwcówce przez Siostry Zmartwychwstanki. W dniu 7 czerwca 1929 roku poświęcono tam kaplicę ku czci św. Teresy od Dzieciątka Jezus, z czego bardzo się cieszyła. Jej duchowe oblicze nosi bowiem wyraźny znak małej drogi dziecięctwa duchowego i jest niejako symbiozą tejże drogi św. Teresy od Dzieciątka Jezus i przesłania Bożego miłosierdzia św. siostry Faustyny Kowalskiej ${ }^{17}$.

Jesienią 1948 roku Kunegunda została dotknięta nieuleczalną chorobą gruźlicy kości i do śmierci pozostawała w łóżku. Zmarła w opinii świętości 27 czerwca 1955 roku. Dwa dni później została pogrzebana na cmentarzu parafii św. Anny w Stryszawie, skąd jej doczesne szczątki 14 listopada 2016 roku zostały przeniesione do kaplicy klasztornej Sióstr Zmartwychwstanek pw. św. Teresy od Dzieciątka Jezus w Siwcówce.

\section{Nadprzyrodzone oświecenia}

W 1942 roku Kundusia, zachęcona przez jedną z zakonnic, aby na spowiedzi wyznawać nie tylko grzechy, ale przedstawiać stan swej duszy, zwierzyła się swemu spowiednikowi, ks. Bronisławowi Bartkowskiemu ${ }^{18}$,

stając się potem wraz z nią współfundatorem klasztoru Sióstr Zmarwtychwstanek i Zakładu Naukowo-Wychwawczego dla Dziewcząt w Siwcówce. Zmarł w Siwcówce i spoczywa na cmentarzu parafialnym w Stryszawie.

15 Główna Księga Bractwa Dzieciątka Jezus z Pragi, zaprowadzona kanonicznie w Wadowicach dnia 25 grudnia 1914 roku, wpis pod rokiem 1923, kol. 1, poz. 19.

16 Spis Sióstr Profesek III Zak. Karm. w Wadowicach od 1893 do 1997 r., s. 52, poz. 361.

17 Bóg prowadził ja droga cierpienia. O Kunegundzie Siwiec i procesie wyniesienia jej na ołtarze mówi dr hab. o. Szczepan T. Praśkiewicz OCD, postulator krakowskiej prowincji Zakonu Karmelitów Bosych, „Cuda i łaski Boże” 2016 nr 10, s. 6.

18 Bronisław Bartkowski (1907-1986), kapłan diecezji chełmińskiej, od 1937 roku do śmierci był kapelanem Sióstr Zmartwychwstanek w Siwcówce i spowiednikiem 
że często, zwłaszcza po Komunii św., słyszy w swym sercu głos Pana Jezusa, a niekiedy także Matki Bożej i świętych ${ }^{19}$. Roztropny kapłan, znający penitentkę od kilku lat, wiedział, że jest ona osobą dojrzałą i niezdolną do zakłamania. Postanowił więc rozeznać dogłębnie cała sprawę. Sam szczerze wyznaje:

W pierwszej chwili byłem tym wyznaniem trochę zaskoczony, tak na wszelki wypadek zacząłem wertować Zarys teologii ascetycznej i mistycznej Tanquerey’a, dzieła św. Teresy z Avila, by na podstawie ich doświadczenia w tej materii urobić sobie jasne zdanie o całej sprawie. Zbyt dobrze od pięciu lat znałem Kundusię, abym ją miał posądzać o jakąś halucynację czy egzaltację, zbyt była rozsądna i zrównoważona duchowo, a przy tym pokorna, by na tej drodze szukać jakiegoś zainteresowania swoją osobą. Zająłem wobec całej sprawy postawę raczej wyczekującą: ani przyjmować bezkrytycznie, ani z miejsca zaprzeczać i odrzucać. Przypomniał mi się Gamaliel i jego zdanie: „Jeżeli od ludzi pochodzi ta myśl czy sprawa, wniwecz się obróci, jeżeli jednak od Boga pochodzi, nie zdołacie jej zniweczyć" (Dz 5, 38-39)20.

Równocześnie, biorąc pod uwagę fakt nieumiejętności pisania przez Kunegundę, światły spowiednik zaczął notować treści, które penitentka podawała mu jako wewnętrzne słyszenie:

Ponieważ poza umiejętnością czytania, z całej sztuki pisania [Kunegunda] opanowała jedynie to, że umiała się podpisać, sam zacząłem robić notatki z jej wypowiedzi, zdając sobie sprawę z tego, że ostateczna opinia o charakterze i treści tych wypowiedzi nie do mnie należy. Starałem się jedynie wiernie i dosłownie notować te zdania, które Kundusia podawała jako wewnętrzne słyszenie. Większość zdań tej mowy wewnętrznej, przez teologów zwanej locutio interna, pochodzi od Jezusa, ale są też i zdania Matki Bożej, świętego Józefa, świętej Teresy Wielkiej, świętej Teresy od Dzieciątka Jezus, świętego Jana od Krzyża, świętej Katarzyny. W sumie przez 13 lat, od 1942 do 1955 roku, zebrało się tych notatek około 100 stron maszynopisu ${ }^{21}$.

Zauważmy nadto, że ks. Bartkowski ustawicznie poszukiwał jakiegoś znaku, potwierdzenia nadprzyrodzonych oświeceń Kunegundy. Widział,

Kunegundy Siwiec. Zob. R. Donajska, Żyć Ewangelia.. Biografia ks. Bronisława Bartkowskiego, spowiednika Stużebnicy Bożej Kunegundy Siwiec, Kraków 2014.

19 Wyznaje to sam ks. Bartkowski w swoim wstępie do Nadprzyrodzonych oświeceń Kunegundy: Głos wewnętrzny, próba, znak, w: Miejsce mojego miłosierdzia i odpoczynku. Nadprzyrodzone oświecenia Kunegundy Siwiec ze Stryszawy, Kraków 2008³, s. 27.

20 Miejsce mojego miłosierdzia i odpoczynku..., dz. cyt., s. 27-28.

${ }^{21}$ Miejsce mojego miłosierdzia i odpoczynku..., dz. cyt., s. 28. 
jak wzrastała ona w zażyłości z Bogiem i nie szukała próżnej chwały, co stanowi zasadnicze kryteria uznania autentyczności prywatnych objawień, ale postanowił jeszcze uzyskać inne tego potwierdzenie. Oddajmy głos jemu samemu:

Wprawdzie co do (...) wypowiedzi Kundusi byłem spokojny, widziałem bowiem dobre owoce jakie one przynosiły, jak rosła w niej szczególnie gorliwość w modlitwie i ofiarach, by pomagać Jezusowi w ratowaniu zagrożonych dusz, (...) to jednak nasunęła mi się myśl, by wartość wypowiedzi (a przez rok zebrało się ich sporo) poddać pewnej próbie. Powiedziałem więc do Kundusi: „Jeśli to rzeczywiście Bóg przemawia, to On zna także moje myśli i pragnienia. Wobec tego proszę, aby spełnił to, co tylko Jemu i mnie jest znane". Chodziło mi o nawrócenie i wyspowiadanie się pewnego grzesznika, który już od kilku lat nie spowiadał się. Stawiałem także warunek, by spowiedź odbyła się 3 maja. Kundusia nic nie wiedząc ani o treści, ani o terminie, modliła się gorąco o spełnienie mojego pragnienia. Nadszedł dzień 3 maja. Po nabożeństwie zasiadłem do konfesjonału. Patrzę, a tu pod chórkiem stoi ów grzesznik. Ludzie powoli poczęli opuszczać kaplicę, a on wtedy wstał i zamiast skierować się do wyjścia - podszedł do konfesjonału. Otrzymałem odpowiedź22.

Należy jeszcze podkreślić, że ks. Bronisław nie naruszył nigdy tajemnicy spowiedzi i miał świadomość jej obowiązku wynikającego z dyscypliny sakramentalnej. Nigdy do śmierci swej penitentki nie wyjawił ani faktu, ani treści jej wewnętrznych doświadczeńn ${ }^{23}$. Ich istnienie objawił dopiero po śmierci Kunegundy, działając zgodnie z wytycznymi Urzędu Nauczycielskiego ${ }^{24}$.

22 Miejsce mojego miłosierdzia i odpoczynku..., dz. cyt., s. 30.

23 Zob. J. Zieliński, Piękno, dz. cyt., s. 93-94.

24 Chodzi głównie o monumentalne wielotomowe dzieło Benedykta XIV De Servorum Dei beatificatione et beatorum canonizatione (Prati 1839-1842), którego reedycja w wersji łacińsko-włoskiej jest w toku w Kongregacji Spraw Kanonizacyjnych od 2010 roku). Czytamy tam, że „confessarius iure divino, naturali et ecclesiastico, prohibetur revelare ea quae in confessione audivit” (spowiednkowi na mocy prawa Bożego, naturalnego i kościelnego zabrania się wyjawiać to, co usłyszał podczas spowiedzi). „Confessarius tamen potest virtutes, revelationes et similes gratias, quas in confessione a Servis Dei audivisset, manifestare post eorum obitum. Confessarii examen de his valde utilis est" (Jednakże spowiednik, cnoty, objawienia i podobne łaski, o których słyszał od Sług Bożych podczas spowiedzi, może objawić po ich śmierci. Przesłuchanie spowiednika w odniesieniu do nich jest bardzo użyteczne) (Liber III, caput 7, n. 1-2 ad 6). W rzeczywistosci w wielu sprawach beatyfikacyjnych posługiwano się jako środkami dowodowymi świadectwami spowiedników. Zresztą sam Benedykt XIV w cytowanym powyżej dziele, napisał, że „pius et humilis confessarius B. Angelae de Fulgineo 
Maszynopis przepisanych zapisków dwa lata po śmierci Kundusi spowiednik pokazał swojemu biskupowi ordynariuszowi Kazimierzowi Kowalskiemu, podczas jego pobytu w Siwcówce. Ordynariusz chełmiński wyraził aprobatę dla tekstu, orzekając, że nie znajduje w nim niczego, co byłoby sprzeczne z wiarą i moralnością chrześcijańską, a wręcz przeciwnie - „wiele pięknych i głębokich myśli”25. Od tego czasu zapis rozmów Chrystusa z Kunegundą był udostępniany różnym osobom zakonnym i świeckim, a nawet Prymasowi Polski, ks. Stefanowi Wyszyńskiemu, który często przybywał na Siwcówkę na rekolekcje i odpoczynek i znał Kunegundę osobiście ${ }^{26}$. Także opinia ks. Prymasa nt. zapisków była pozytywna i polecał je czytać członkiniom Instytutu Prymasowskiego ${ }^{27}$.

W 1995 roku zapiski ukazały się drukiem w Wydawnictwie Karmelitów Bosych w Krakowie ${ }^{28}$. Starania o ich wydanie podejmowało wiele osób, przede wszystkim pani Helena Faustyna Stańczyk, znana propagatorka

omnia scriptis mandabat, quae sibi a Beata poenitentiae communicabantur" (pobożny i pokorny spowiednik bł. Anieli z Foligno [wpisanej w 2013 roku przez papieża Franciszka do katalogu świętych] wszystko notował, co mu Błogosławiona w sakramencie pokuty podawała) (Liber II, caput 26, n. 1). Zdanie spowiedników było brane pod uwagę m.in. w procesach św. Teresy od Jezusa, św. Ludwika, św. Katarzyny Sjeneńskiej, św. Franciszki Rzymianki czy św. Małgorzaty z Kortony, a w ostatnich latach sług Bożych Marii Oliwii Bonaldo (zm. 1976) i Marii Scholastyki Rivata (zm. 1987). Zob. Sz. T. Praśkiewicz, Czy zapiski spowiednika mogą stanowić podstawę do rozpoczęcia procesu beatyfikacyjnego i mieć $w$ tym procesie wartość dowodowa??, w: Świętość kanonizowana, red. Sz. T. Praśkiewicz, Kraków 2014, t. 12, s. 68-69.

25 B. Bartkowski, Głos wewnętrzny, dz. cyt., s. 28.

26 Czcig. Sł. B. Stefan Wyszyński, jak relacjonuje jego bliska współpracowniczka Maria Okońska w liście z dn. 13 marca 1991 (sygn. T2C/22 w Archiwum Biura Postulatorskiego Krakowskiej Prowincji Karmelitów Bosych w Krakowie), poznał Kunegundę osobiście jeszcze jako biskup lubelski w sierpniu 1946 roku, gdy w kaplicy w Siwcówce prowadził rekolekcje dla dziewcząt i pań formujących Instytut Świecki Pomocnic Maryi Jasnogórskiej, Matki Kościoła, zwany popularnie Ósemką Prymasowską (dziś Instytut Prymasowski). Do uczestnictwa w naukach rekolekcyjnych zaprosił także Kunegundę, z czego ochotnie skorzystała. Odwiedzał ją też w domu w latach następnych, już jako prymas i prosił o modlitwę w różnych ważnych sprawach (zob. J. Zieliński, Piękno, dz. cyt., s. 95-96); O relacjach Prymasa z Kunegundą wspominają także niektórzy świadkowie w procesie beatyfikacyjnym Służebnicy Bożej, do zeznań których mieliśmy dostęp jako postulator w tymże procesie. Świadectwa te są jednak objęte urzędową tajemnicą i nie możemy ich zacytować.

27 Zob. H. F. Stańczyk, Kundusia z Siwcówki, dz. cyt., Kraków 1996, s. 75.

${ }_{28}$ Miejsce mojego Miłosierdzia i Odpoczynku. Nadprzyrodzone oświecenia Kunegundy Siwiec ze Stryszawy zanotowane przez ks. Bronisława Bartkowskiego, Kraków 1995. W 1998 roku dokonano dodruku książki w takiej samej szacie graficznej, a w roku 2008 i 2012 ukazały się nowe 
opinii świętości Kunegundy i autorka pierwszych o niej publikacji ${ }^{29}$. Książka otrzymała wymowny tytuł Miejsce mojego miłosierdzia i odpoczynku - zaczerpnięty z tychże Nadprzyrodzonych oświeceń, w których Pan Jezus kilkakrotnie dał słyszeć Kunegundzie, że serce jej samej, a nadto miejsce, w którym żyła, wybrał na miejsce swojego miłosierdzia i odpoczynku, z którego pragnie na całą ludzkość wylewać zdroje swego miłosierdzia i czynić cuda miłości ${ }^{30}$. Oczywiście, książka przed wydaniem została zbadana przez teologów i pozytywnie przez nich oceniona, poddana oficjalnej cenzurze kościelnej, została opatrzona „imprimatur” Krakowskiej Kurii Metropolitalnej (Nr 667/1995). Książka wzbudziła zainteresowanie wielu osób w różnorodnych środowiskach.

Jak to zauważyliśmy gdzie indziej ${ }^{31}$, z zapisanych przez spowiednika rozmów Służebnicy Bożej z Chrystusem i świętymi wynika jednoznacznie, że ustawicznie kierowała się ona głęboką wiarą i żarliwą miłością Boga oraz bliźniego, żywiąc równocześnie teologalną nadzieję osiągnięcia życia wiecznego. Wzrastała w tych cnotach z dnia na dzień pod kierownictwem samego Pana Jezusa i Jego Matki, dążąc do ścisłego zjednoczenia z Bogiem. Równocześnie podejmowała praktykę pozostałych cnót ewangelicznych, szczególnie prostoty, cichości i pokory, a nadto cierpliwości, oderwania się od siebie i od spraw tego świata. Była bez reszty oddana Bogu i trosce o zbawienie własne i bliźnich. Każdy, kto zagłębi się w lekturze jej Nadprzyrodzonych oświeceń spotka się na ich kartach z czytelnym świadectwem o pięknie głębokiego życia duchowego na usługach zbawczych Jezusa Chrystusa w Jego Kościele.

jej wydania, zawsze w Wydawnictwie Karmelitów Bosych w Krakowie. W naszym artykule posługujemy się wydaniem z 2008 roku.

${ }_{29}$ H. F. Stańczyk, Kundusia z Siwcówki, „List” 1994 nr 4, s 12-14; H. F. Stańczyk, Kundusia z Siwcówki (Kunegunda Siwiec), Kraków 1996; H. F. Stańczyk, Kunegunda Siwiec, Kraków 1999.

30 Miejsce mojego miłosierdzia i odpoczynku..., dz. cyt., s. 77, 114, 201, 216.

31 Stowo postulatora w procesie beatyfikacyjnym, w: Miejsce, dz. cyt., s. 7-8. 


\section{Przesłanie Służebnicy Bożej}

Spośród wielu wątków, jakie jawią się w przesłaniu Kunegundy Siwiec i które mają szczególną wymowę w dzisiejszych czasach, wybierzmy jedynie dwa. Wydają się nam one szczególnie aktualne i mogą stanowić przeciwwagę wobec prądów i tendencji, z jakimi borykamy się w otaczającym nas świecie.

Przywołajmy więc najpierw - wobec kryzysu rodziny, jakiego doświadcza nasze społeczeństwo i co stwierdził Synod Biskupów z 2015 roku, a następnie adhortacja Amoris laetitia ${ }^{32}$ - obraz poprawnego życia rodzinnego wyłaniający się z Nadprzyrodzonych oświeceń Kunegundy z wielodzietnej rodziny babiogórskich górali.

Później zaś, inspirując się słowami Jana Pawła II o szerzącej się w naszym społeczeństwie kulturze śmierci, która prowadzi do eutanazji ${ }^{33}$, chciejmy spojrzeć na zbawcze ofiarowanie cierpienia przez Kunegundę, stanowiące dojrzały sprzeciw wobec „pogodnej śmierci”.

\subsection{Poprawne życie rodzinne ${ }^{34}$}

Rodzice Kunegundy, górale babiogórscy, byli - jak już wspomnieliśmy - ludźmi pracowitymi i bogobojnymi. W ich domu zawsze panował porządek. Wiktoria, żona, była pobożną niewiastą, zatroskaną matką i zapobiegliwą gaździną, a jej mąż Jan pracowitym gazdą, dobrym ojcem i religijnym, prawym człowiekiem, pogodnym, opowiadającym

32 Zob. Synod Biskupów. XIV Zwyczajne Zgromadzenie Ogólne, Relacja końcowa, Città del Vaticano 2015, nr 5-7; Amoris laetitia, nr 32-34, gdzie jest m.in. mowa o nieokiełzanym indywidualizmie, który wynaturza więzi rodzinne, o unikaniu wśród młodych osób definitywnych zobowiązań we wzajemnych relacjach i podejmowaniu życia z partnerem bez zawierania małżeństwa, o rewolucji seksualnej i narastaniu mentalności antykoncepcyjnej i aborcyjnej, o pladze separacji i rozwodów.

${ }_{33}$ Por. Jan Paweł II, Posynodalna adhortacja apostolska Ecclesia in Europa, Città del Vaticano 2003, nr 88.

34 Z. Sz. T. Praśkiewicz, Rodzina w ujęciu nowych karmelitańskich kandydatów na ołtarze, w: Rodzina u Świętych Karmelu, red. Jerzy W. Gogola, Kraków 2013, s. 155-158 (Karmel Żywy, 16). 
ciekawe historie i przypowieści gawędziarzem. Środowisko „Siwców szanowało" 35 . U nich nie było pijaństwa, nie chodzili grać w karty czy plotkować, ale dbali o życie rodzinne. A była to rodzina liczna, bo Siwcowie dali życie jedenaściorgu dzieciom, dbali o ich religijne wychowanie i przystępowanie do sakramentów. Jakkolwiek do kościoła w Suchej Beskidzkiej było daleko (kilka godzin marszu), rodzice dawali dzieciom przykład coniedzielnego uczestnictwa w Eucharystii, a w domu codziennego pacierza. Dzieci Siwców bardzo szanowały ojca i matkę i chętnie pomagały w pracach gospodarczych.

Kunegunda, od 24 czerwca 1923 roku tercjarka karmelitańska, chociaż sama świadomie zrezygnowała z życia małżeńskiego, doceniała wartość rodziny. W swym apostolstwie służyła radą także narzeczonym, a niektóre pary korzystały u niej, za radą proboszcza, niejako z kursów przedmałżeńskich ${ }^{36}$.

Ale służebnica Boża Kunegunda znana jest przede wszystkim ze swych Nadprzyrodzonych oświecen, w których wielokrotnie pojawia się tematyka rodziny. Dwukrotnie Kundusia słyszała na temat rodziny głos Maryi: Matka Najświętsza zapewniała ją, że „sprawi u Syna by zgoda i pokój zapanowały w pewnej rodzinie" (o co Kunegunda prosiła) ${ }^{37}$; nadto Jezusowa Matka pouczała swoją rozmówczynię:

Rodzice ziemscy kochają wszystkie dzieci, ale więcej te, które nie czynią im przykrości, darzą je większymi darami. Dusze wierne uprzywilejowane są łaskami. Dusze takie doznają mojej czułej opieki, a i rodzina takich dusz doznaje szczególnej opieki ${ }^{38}$.

Częściej tematyka rodziny oraz kwestia relacji rodziców z dziećmi pojawia się w głosie słyszanym przez Kundusię od Pana Jezusa. Podsumowując te nadprzyrodzone oświecenia, zauważamy w nich następujące pouczenia: trzeba ufać Panu Bogu, tak jak dzieci ufają swoim rodzicom, i trzeba kochać Boga spontanicznie, na wzór spontanicznej miłości dzieci

\footnotetext{
J. Zieliński, Piękno ukryte w prostocie, dz. cyt., s. 24.

Zob. J. Zieliński, Piękno ukryte w prostocie, dz. cyt., s. 58-60.

Miejsce mojego miłosierdzia i odpoczynku..., dz. cyt., s. 35.

Miejsce mojego miłosierdzia i odpoczynku..., dz. cyt., s. 126.
} 
wobec rodziców ${ }^{39}$; jak dzieci tęsknią za obecnością rodziców, tak trzeba tęsknić za Bogiem ${ }^{40}$; trzeba przejawiać prostotę i szczerość na wzór dzieci i garnąć się do Pana, jak dzieci do rodziców - one w objęciach rodziców się nie boją i tak powinno być z nami, gdy staramy się być w rękach Bożych ${ }^{41}$; rodzice najbardziej miłują najmniejsze dzieci, trzeba więc starać się należeć do liczby maluczkich ${ }^{42}$; nawet gdy dzieci nie myślą o rodzicach, ustawicznie są przez nie kochane, podobnie jak my przez Pana Boga ${ }^{43}$; gdy dzieci kochają rodziców, to rodzice wybaczają im ich pomyłki - Pan Bóg zaś tak czyni wobec nas ${ }^{44}$; tak jak rodzice przyozdabiają dzieci pięknymi ubrankami, tak Bóg przyozdabia nas szatą swej łaski $\mathrm{i}^{45}$; w końcu nie ważne jest to, co małe dzieci zrobią dla rodziców, ale jaką miłością ich kochają, rodzice zaś kochają szczególnie te dzieci, które przynoszą im radośćc ${ }^{46}$, a dzieci bronią rodziców, gdy dzieje się im krzywda ${ }^{47}$. Czyż to nie kompletny obraz prawdziwego życia rodzinnego?

\subsection{Zbawcza wartość cierpienia ${ }^{48}$}

Święty Jan Paweł II, czyniąc się wyrazicielem treści, jakie były przedmiotem rozwagi Synodu Biskupów Europejskich, obradujących w Watykanie w 1999 roku, w posynodalnej adhortacji apostolskiej Ecclesia in Europa napisał, że „w [europejskim] społeczeństwie dobrobytu i wydajności, w kulturze, którą cechuje bałwochwalczy kult ciała, [następuje] wypieranie ze świadomości bólu i cierpienia oraz [panuje] mit wiecznej młodości" ${ }^{49}$. Papież stwierdził nadto, że we współczesnej kulturze

39 Zob. Miejsce mojego miłosierdzia i odpoczynku..., dz. cyt., s. 80, 89, 109.

40 Zob. Miejsce mojego miłosierdzia i odpoczynku..., dz. cyt., s. 98, 124.

41 Zob. Miejsce mojego miłosierdzia i odpoczynku..., dz. cyt., s. 122, 135, 146, 154.

42 Zob. Miejsce mojego miłosierdzia i odpoczynku..., dz. cyt., s. 93, 109, 123, 125, 141, 146.

43 Zob. Miejsce mojego miłosierdzia i odpoczynku..., dz. cyt., s. 122.

44 Zob. Miejsce mojego mitosierdzia i odpoczynku..., dz. cyt., s. 89.

45 Zob. Miejsce mojego miłosierdzia i odpoczynku..., dz. cyt., s. 121.

46 Zob. Miejsce mojego miłosierdzia i odpoczynku..., dz. cyt., s. 92, 108, 118, 120, 135, 143.

47 Zob. Miejsce mojego miłosierdzia i odpoczynku..., dz. cyt., s. 83.

48 Zob. Sz. T. Praśkiewicz, Święci i słudzy Boży polskiego Karmelu terezjańskiego wobec problemów $i$ wyzwań obecnych czasów, Kraków 2010, s. 202-204 (Itinera Spiritualia, 3).

49 Jan Paweł II, Ecclesia in Europa, nr 88. 
zachodniej coraz bardziej rozpowszechnia się agnostycyzm religijny, związany z pogłębiającym się relatywizmem moralnym i prawnym, którego oznaką są niepokojące formy tego, co można nazwać „kulturą śmierci" ${ }^{\prime 50}$. Ta zaś kultura rodzi tendencję do uważania, jakoby dopuszczalne było świadome położenie kresu życiu, własnemu czy innej istoty ludzkiej, co znane jest pod nazwą eutanazji, występującej w sposób zamaskowany czy dokonywanej jawnie, gdyż istnieją smutne przypadki jej legalizacji i nie brak żądań, aby jej dopuszczalność została powszechnie uznana ${ }^{51}$.

Zauważmy, że na kwestię eutanazji, jako na jedną z najgroźniejszych patologii społecznych wskazuje też II Polski Synod Plenarny ${ }^{52}$. Synod mówi też o rozpaczy, do jakiej często doprowadza człowieka hedonistyczna antykultura, czego konsekwencją bywa nawet pokusa „wyeliminowania źródła problemów przez położenie kresu swemu życiu, gdy staje ono w obliczu najgłębszych pytań egzystencji, na które nie znajduje odpowiedzi"53.

Postawę, jakże na wskroś przeciwną tej mentalności prezentuje Kunegunda Siwiec swoim przykładem akceptacji cierpienia i nadania mu zbawczego wymiaru. Jesienią 1948 roku została ona dotknięta nieuleczalną chorobą gruźlicy kości i do śmierci w 1955 roku pozostawała w łóżku.

W czasie rozmów z różnymi osobami Kunegunda często powtarzała, że do nieba nie możemy iść sami, ale że trzeba przyprowadzać tam innych, ofiarując za nich swoje cierpienie. Jej oddanie się Chrystusowi szło w parze z miłością do ludzi. Najpierw prowadziła ich do Niego poprzez apostołowanie słowem, katechezę, które popierała modlitwą. A gdy Pan

50 Jan Paweł II, Ecclesia in Europa, nr 9.

51 Jan Paweł II, Ecclesia in Europa, nr 95.

52 Czytamy w jego aktach: „Do najgroźniejszych patologii społecznych prowadzi nieumiejętne korzystanie ze zdobyczy cywilizacyjnych, postawa konsumpcyjna, obniżenie autorytetu rodziny oraz brak szacunku dla ludzkiego życia, który przejawia się agresją wobec nie narodzonych dzieci i szukaniem rozwiązania problemów starości na drodze eutanazji" Drugi Polski Synod Plenarny (1991-1999), Poznań 2001, s. 222-223.

53 Drugi Polski Synod Plenarny (1991-1999), dz. cyt., s. 18. 
nawiedził ją chorobą, nie opierała się w przyjmowaniu cierpień, lecz właśnie z nich uczyniła narzędzie ewangelizacji.

Ogrom jej cierpień opisał nam spowiednik:

Już wcześniej skarżyła się na dotkliwy ból w kolanie, teraz jednak ból ten staje się tak dotkliwy, że trudno się jej poruszać. Miejsca bolesne zaczynają puchnąć, zjawiają się też obrzęki na ręce. Kundusia zmuszona jest położyć się do łóżka, którego już nie opuści aż do śmierci. Zaś łoże boleści staje się coraz bardziej drzewem krzyżowym. Boleści wzmagają się, dochodzi do tego, że najmniejsze dotknięcie powoduje atak silnego bólu (...). Przez pół roku Kundusia leży tylko na jednym boku i tak sypia, a raczej drzemie, bo bóle nie pozwalają spać, ani obrócić się na drugi bok. Wszelkie środki lekarskie i próby leczenia zawodzą. (...) Dwa lata przed śmiercią, gruźlica, która zaatakowała kości, teraz prawdopodobnie przerzuciła się na organy wewnętrzne. Następują wyczerpujące krwotoki wewnętrzne i wzmaga się jednocześnie bezsenność ${ }^{54}$.

Świadkowie życia Kunegundy wspominają, że nigdy się nie skarżyła na swój los, a gdy starali się ją pocieszać, odpowiadała, że swoje cierpienie ofiaruje Panu Jezusowi za kapłanów, by promieniowali świętością życia, i za zbawienie bliźnich. Ludzie ustawicznie prosili ją o modlitwę. Mawiała wówczas w swoim dialekcie: „Jo tako zwykło dziopa, jo nic nie znace, ale poprose Pana Jezusa" ${ }^{\prime 5}$, i wypraszała liczne łaski. Cytowany już spowiednik kontynuuje:

I przy tym wszystkim [tj. ogromnym cierpieniu] Kundusia zachowuje niezmąconą pogodę ducha. Poza atakami silnych bólów, z twarzy jej nie schodzi wyraz pokoju i pogodny uśmiech. I ona, wydawałoby się, sama tak bardzo potrzebująca pociechy, pociesza z całą gorącością swego życzliwego serca tych, co do niej przychodzą ze swymi małymi i wielkimi strapieniami. Mocą jej jest Jezus. Kiedyś zwierzyła mi się mówiąc: „Dziwię się, jak ludzie mogą choć na chwilę radzić sobie bez Jezusa. Bez Niego czułabym się niezdolna znieść choćby najmniejszej przeciwności!" Nic dziwnego, że Jezus nieustannie podtrzymywał ją na duchu, sam w niej cierpiąc ${ }^{56}$.

${ }^{54}$ B. Bartkowski, Wstęp, w: Miejsca Mojego miłosierdzia i odpoczynku, Kraków 200833, s. 22-23.

55 Wspomnienie s. Zenony Połońskiej CR (1987), Archiwum Biura Postulatorskiego Krakowskiej Prowincji Karmelitów Bosych, sygn. T2B/9, s. 2.

56 B. Bartkowski, Wstęp, dz. cyt., s. 23 
Zagadnienie cierpienia w życiu służebnicy Bożej przeanalizował dogłębnie dr Piotr Marceli Strojecki ${ }^{57}$. Stwierdził, że było ono cierpieniem przemieniającym, ofiarowanym za bliźnich, zwłaszcza za zbawienie grzeszników. Słowem, w myśl teologii paulińskiej, było ono cierpieniem, poprzez które dopełniała w swym ciele „,braki udręk Chrystusa dla dobra Jego Ciała, którym jest Kościół” (Kol 1, 24).

Myśl o eutanazji, czyli o porwaniu się na własne życie nigdy nawet nie zaświtała w umyśle Kunegundy; była też ona zupełnie obca osobom, które się nią opiekowały. Służebnica Boża stawała się ze swego łoża „głosicielką Ewangelii życia"58, a opiekujące się nią osoby, jakkolwiek nie mogły ulżyć jej cierpieniom, ofiarowały jej „ciepło autentycznego kontaktu ludzkiego" ${ }^{59}$.

\section{Zakończenie}

Fenomen Kunegundy Siwiec, prostej niepiśmiennej kobiety z Podbeskidzia, to nic innego, jak dogłębnie zrozumiana i wcielona w życie Ewangelia. Kiedyś, odwiedzając jeden z polskich klasztorów karmelitańskich, kard. Karol Wojtyła nawiązał do św. Teresy od Dzieciątka Jezus i do jej drogi duchowego dziecięctwa, mówiąc:

Św. Teresa „przypomniała światu, że w ekonomii Bożej to, co wielkie, co największe, jest właśnie małe i ukryte. I odwrotnie to, co wielkie, co potężne, co głośne, jest najmniejsze". I to się bardzo utrwaliło na kliszy współczesnego Kościoła i winno się utrwalić także i w naszej świadomości, aby stać się naszym życiowym programem $\mathrm{w}$ postępowaniu za Jezusem ${ }^{60}$.

Fenomenem „Kundusi” jest właśnie ta ewangeliczna maleńkość, która staje się jej wielkością.

57 P. M. Strojecki, „Umiłuj mój Krzyż”. Cierpienie według Miejsca Mojego miłosierdzia i odpoczynku, dz. cyt., s. 66-73.

58 Jan Paweł II, Ecclesia in Europa, nr 96.

59 Jan Paweł II, Ecclesia in Europa, nr 88.

60 Kalendarium życia Karola Wojtyły, opr. A. Boniecki, Kraków 1983, s. 655. 
Wiemy, że dobre zasady wszczepione człowiekowi od samego dzieciństwa owocują potem w całym jego życiu. Tak właśnie było w życiu Kunegundy. Środowisko, z którego się wywodziła, to świat ludzi prostej, głębokiej, zadziwiającej dzisiejszego człowieka i chyba nie w pełni dla niego zrozumiałej wiary i pobożności. Co więcej, to świat szczególnej pracowitości i prostoty, idących w parze ze szlachetnością i prostolinijnością, a nadto świat wyrzeczeń, jakich żądały górski klimat i przyroda. Wszystko to nie mogło nie mieć wpływu na życiowe decyzje Kunegundy. Jej życie było tak proste, jak prosta jest góralska codzienność. Można je streścić w kilku zdaniach: po dzieciństwie, jakie upłynęło jej bogobojnie we wspomaganiu rodziców i rodzeństwa, nauce czytania (i nieco pisania) w zimowe wieczory, a także po planach zamążpójścia, Kunegunda, zauroczona Bogiem podczas misji parafialnych, zmieniła zdanie i poświęciła się wyłącznie Bogu, jako osoba świecka. Po kursie katechetycznym w Sidzinie przygotowywała dzieci i dorosłych do sakramentów. Wstąpiwszy do Świeckiego Zakonu Karmelitańskiego zafascynowała się drogą duchowego dziecięctwa św. Teresy. Jako spadkobierczyni swego rodu przekazała część ziemi pod budowę kaplicy i klasztoru Sióstr Zmartwychwstanek. Dotknięta chorobą siedem lat cierpiała przykuta do łóżka, nigdy się nie skarżąc.

W tym wszystkim, w tej „maleńkości” pojawił się jednak Ktoś - Bóg i Jego „głosy”, które słyszała w swoim sercu, z czego się nie chełpiła, ale czym żyła i co potwierdzała, utożsamiając się z cierpiącym Jezusem dla zbawienia świata.

Dlatego też dzisiejszemu człowiekowi, niezależnie od jego stanu, wykształcenia, posiadanych dóbr, wciąż zagonionemu, poddanemu stresom i hałasowi współczesnego świata, w epoce kryzysu wartości moralnych i krytyki wszelkich autorytetów, człowiekowi wyzutemu z wartości duchowych, targanemu ubóstwem rodziny, kontestującemu zbawczą wartość cierpienia i proponującemu „pogodną śmierć” przez eutanazję, Kunegunda Siwiec przypomina i ofiaruje przesłanie Ewangelii i orędzie Karmelu, które ukierunkowują na głębię i na życie duchowe, bez zapominania o obowiązkach codzienności. Ta prosta wiejska kobieta i równocześnie osoba wielkiej kultury duchowej i głębokiej zażyłości z Panem Bogiem potwierdza to przykładem, świadectwem swego życia, 
co - jak widzieliśmy - pociąga i urzeka wiele osób ${ }^{61}$, które gromadzą się wokół niej. Kundusia przypomina wszystkim, że „nie mamy tutaj trwałego miasta, ale szukamy tego, które ma przyjść” (Hbr 13, 14). Wciąż uczy, że „wznosząc budowlę tego świata”, trzeba równocześnie troszczyć się o życie duchowe i ukierunkowywać je ku „światu, który ma nadejść"62.

61 Należy do nich m.in. znany eseista Lech Jęczmyk (ur. 1931). Zob. L. Jęczmyk, Trzy końce historii, czyli Nowe Średniowiecze, Poznań 2006, s. 350 (i 4 okładki).

62 Jan Paweł II, Ecclesia in Europa, nr 97-99. 


\section{Summary}

\section{Kunegugda Siwiec ze Stryszawy: osoba i przesłanie}

Ciągle wzrastające zainteresowanie Kunegundą Siwiec (1876-1955), świecką karmelitanką objętą procesem kanonicznym zmierzającym do wyniesienia jej na ołtarze, postuluje poznanie jej osoby i przesłania. Ta prosta wiejska, niepiśmienna kobieta, zaangażowana w życie modlitwy i apostolstwo, zatroskana o autentyczne życie religijne $\mathrm{w}$ rodzinach, była odbiorczynią Nadprzyrodzonych oświeceń, tj. rozmów wewnętrznych z Chrystusem, Jego Matką i niektórymi świętymi, jakie spisał jej spowiednik, ks. Bronisław Bartkowski. Nie chełpiąc się tymi duchowymi doświadczeniami, ale żyjąc cnotliwie, doświadczyła długoletniej obłożnej i bolesnej choroby, stając się przykładem pogodnego znoszenia cierpienia, przeżywanego w duchu paschalnym i ofiarowanego za zbawienie bliźnich.

Słowa kluczowe: Kunegunda Siwiec, życie, rodzina, cierpienie

\section{Kunegunda Siwiec from Stryszawa: a person and a message}

Constantly growing interest of Kunegunda Siwiec (1876-1955), a secular Carmelite, being under the canonical process, aiming to elevate her to the altars, postulates to know her and her messages. This simple rural, illiterate woman, engaged in the life of prayer and apostolate, concerned about the authentic religious life in the families, was the recipient of the Supernatural Enlightenment, e.g. internal conversations with Christ, His Mother and some Saints, was written down by her confessor, Fr. Bronisław Bartkowski. She did not boast about these spiritual experiences, but lived virtuous life experiencing a bedridden long-time painful disease, becoming an example of the cheerfully enduring suffering and lived in the Paschal Spirit sacrificing herself for the salvation of others.

Keywords: Kunegunda Siwiec, life, family, suffering

\section{Bibliografia}

Adamska J. I., Dlaczego właśnie Kundusia z Siwcówki, Tczew-Pelplin 1998.

Donajska R., Żyć Ewangelia. Biografia ks. Bronisława Bartkowskiego, spowiednika Służebnicy Bożej Kunegundy Siwiec, Kraków 2014.

Gogola J. W., Doświadczenie mistyczne Kundusi Siwiec, w: J. W. Gogola, Mistyka i mistycy Karmelu, Kraków 2007, s. 379-391.

Górnik S., Doświadczenie mistyczne Rozalii Celak i Kunegundy Siwiec. Przesłanie dotyczace przyszłości Polski i świata, Lublin 2006. 
Jan Paweł II, Posynodalna adhortacja apostolska Ecclesia in Europa, Città del Vaticano 2003.

Kalniuk T., A folk mystic - Cunegonde Siwiec from Stryszawa, http://kundusia.pl/sites/default/files/A_folk_mystic-Cunegonde_Siwiec_from_Stryszawa.pdf(4.01.2019).

Kucharski B., Miejsce Bożego Miłosierdzia i Odpoczynku - Kunegunda Siwiec (1876-1955), w: B. Kucharski, Kobiety Bożego Miłosierdzia, Kraków 2007, s. 125-137.

Łączkowska A., Eklezjalny wymiar posłannictwa Kunegundy Siwiec, Poznań 2008.

Marsili A., Siwiec Cunegonda, serva di Dio, w: Bibliotheca Sanctorum. Terza appendice, Roma 2013, s. 1087-1089.

Miejsce mojego miłosierdzia i odpoczynku. Nadprzyrodzone oświecenia Kunegundy Siwiec ze Stryszawy, zebrane przez ks. Bronisława Bartkowskiego, Kraków $2008^{3}$.

Praśkiewicz Sz. T., Cunegonda Siwiec OCDS en camino hacia los altares, Kraków 2012, s. 165-176 (Itinera spiritualia, 5).

Praśkiewicz Sz. T., Czy zapiski spowiednika moga stanowić podstawę do rozpoczęcia procesu beatyfikacyjnego i mieć w tym procesie wartość dowodowa?, red. Sz. T. Praśkiewicz, Kraków 2014, s. 61-73 (Świętość Kanonizowana, 12).

Praśkiewicz Sz. T., Rodzina w ujęciu nowych karmelitańskich kandydatów na ottarze, w: Rodzina u Świętych Karmelu, red. J. W. Gogola, Kraków 2013, s. 155-158 (Karmel Żywy, 16).

Praśkiewicz Sz. T., Święci i słudzy Boży polskiego Karmelu terezjańskiego wobec problemów i wyzwań obecnych czasów, Kraków 2010, s. 197-223 (Itinera Spiritualia, 3).

Przybyszewski B., Blaszyński Wojciech, w: Encyklopedia katolicka, t. 2, Lublin 1976, s. 657.

Sesja kommemoracyjna o Kunegundzie Siwiec, red. W. Tochmański, E. i S. Leśniewscy, Kraków 2006 (Żyć Karmelem w Świecie, nr specjalny).

Stuga Boża Kunegunda Siwiec, „Cuda i Łaski Boże” 2016 nr 10.

Stańczyk H. F., Kundusia z Siwcówki (Kunegunda Siwiec), Kraków 1996.

Stańczyk H. F., Kunegunda Siwiec, Kraków 1999.

Strojecki P. M., Rozwój życia duchowego Kunegundy Siwiec(1876-1955), w: Nova et vetera polskiej duchowości, red. M. Chmielewski, Lublin 2004, s. 208-227.

Strojecki P. M., Życie duchowe Kunegundy Siwiec na podstawie „Miejsca mojego mitosierdzia i odpoczynku", Radzymin 2004.

Urbański S., Kunegunda Siwiec (1876-1955), mistyka Trójcy Świętej, w: S. Urbański, Mistyczki Niepodległej Polski 1918-2018: przesłanie Jezusa, Warszawa 2018, s. 136-144.

Walczak A., Beskidzka katedra Prymasa Tysiąclecia, Stryszawa 2002.

Wisiecka-Jęczalik H., Terezjańska droga Kunegundy Siwiec 1876-1955, Wrocław 2001.

Zieliński J., Piękno ukryte w prostocie. Życie Służebnicy Bożej Kunegundy Siwiec OCDS, Kraków 2010. 